\title{
ATP-Binding Pocket-Targeted Suppression of Src and Syk by Luteolin Contributes to Its Anti-Inflammatory Action
}

\author{
Jeong-Oog Lee, ${ }^{1}$ Deok Jeong, ${ }^{2}$ Mi-Yeon Kim, ${ }^{3}$ and Jae Youl Cho ${ }^{2}$ \\ ${ }^{1}$ Department of Aerospace, Information Engineering, Bio-Inspired Aerospace Information Laboratory, \\ Konkuk University, Seoul 143-701, Republic of Korea \\ ${ }^{2}$ Department of Genetic Engineering, Sungkyunkwan University, Suwon 440-746, Republic of Korea \\ ${ }^{3}$ School of Systems Biological Science, Soongsil University, Seoul 156-743, Republic of Korea
}

Correspondence should be addressed to Deok Jeong; gamad86@nate.com, Mi-Yeon Kim; kimmy@ssu.ac.kr, and Jae Youl Cho; jaecho@skku.edu

Received 2 March 2015; Accepted 15 April 2015

Academic Editor: Jan G. C. van Amsterdam

Copyright (C) 2015 Jeong-Oog Lee et al. This is an open access article distributed under the Creative Commons Attribution License, which permits unrestricted use, distribution, and reproduction in any medium, provided the original work is properly cited.

\begin{abstract}
Luteolin is a flavonoid identified as a major anti-inflammatory component of Artemisia asiatica. Numerous reports have demonstrated the ability of luteolin to suppress inflammation in a variety of inflammatory conditions. However, its exact antiinflammatory mechanism has not been fully elucidated. In the present study, the anti-inflammatory mode of action in activated macrophages of luteolin from Artemisia asiatica was examined by employing immunoblotting analysis, a luciferase reporter gene assay, enzyme assays, and an overexpression strategy. Luteolin dose-dependently inhibited the secretion of nitric oxide (NO) and prostaglandin $\mathrm{E}_{2}\left(\mathrm{PGE}_{2}\right)$ and diminished the levels of mRNA transcripts of inducible NO synthase (iNOS), tumor necrosis factor(TNF-) $\alpha$, and cyclooxygenase-2 (COX-2) in lipopolysaccharide- (LPS-) and pam3CSK-treated macrophage-like RAW264.7 cells without displaying cytotoxicity. Luteolin displayed potent NO-inhibitory activity and also suppressed the nuclear translocation of NF- $\kappa$ B (p65 and p50) via blockade of Src and Syk, but not other mitogen-activated kinases. Overexpression of wild type Src and point mutants thereof, and molecular modelling studies, suggest that the ATP-binding pocket may be the luteolin-binding site in Src. These results strongly suggest that luteolin may exert its anti-inflammatory action by suppressing the NF- $\kappa$ B signaling cascade via blockade of ATP binding in Src and Syk.
\end{abstract}

\section{Introduction}

Artemisia asiatica Nakai is medicinal plant used as a clinically prescribed drug for treating gastritis and gastric ulcer in Korea $[1,2]$. Indeed, it was found that an ethanolic extract of this plant can suppress the formation of gastric ulcers induced by $\mathrm{HCl} / \mathrm{EtOH}$ in mice [3]. Previous phytochemical studies indicated that flavonoids including eupatilin, jaceosidin, and luteolin are major anti-inflammatory components [3-6]. It was found that eupatilin is capable of suppressing aortic smooth muscle cell proliferation and migration by inhibiting the activities of PI3K, MKK3/6, and MKK4 [7]. In an in vivo experiment, this compound also displayed a neuroprotective activity against ischemia/reperfusion-derived neuronal damage in mice [8]. Mechanistically, eupatilin was examined for its ability to suppress LPS-induced inflammatory gene expression via inhibition of nuclear factor- (NF-) $\kappa \mathrm{B}-$ dependent pathways.

Many studies have been performed on the antiinflammatory action of luteolin. It has been found that this compound is capable of suppressing the production of inflammatory mediators such as tumor necrosis factor(TNF-) $\alpha$, interleukin- (IL-) 8 , nitric oxide (NO), reactive oxygen species (ROS), and prostaglandin $\mathrm{E}_{2}\left(\mathrm{PGE}_{2}\right)$ and inhibiting their corresponding genes, such as inducible NO synthase (iNOS) and cyclooxygenase-2 (COX-2), in peritoneal macrophages, RAW264.7 cells, and BV2 cells [9-11]. The two pathways inhibited by luteolin have been identified as being the NF- $\kappa \mathrm{B}$ pathway, mediated through inhibition of phosphatidylinositol 3-kinase (PI3K) and AKT [12]; and the activator protein- (AP-) 1 pathway, mediated through inhibition of extracellular-signal-regulated kinase 
1/2 (ERK1/2), p38, and c-Jun N-terminal kinase (JNK) $[13,14]$.

Although many researchers have studied the immunopharmacological activities of luteolin, the targets of this compound have not been fully elucidated. In this study, therefore, we undertook to identify the molecular targets of luteolin involved in the regulation of LPS-stimulated macrophages.

\section{Materials and Methods}

2.1. Materials. Flavonoids (luteolin, jaceosidin, and eupatilin) (Figure 1(a)), indomethacin (Indo), N-nitro-L-argininemethyl ester (L-NAME), polyethylenimine (PEI), 3-(4,5dimethylthiazol-2-yl)-2,5-diphenyltetrazolium bromide (a tetrazole) (MTT), sodium dodecyl sulfate (SDS), dimethyl sulfoxide (DMSO), pam3CSK, and lipopolysaccharide (LPS, E. coli 0111:B4) were purchased from Sigma-Aldrich Co. (St. Louis, MO, USA). An ethanolic extract of Artemisia asiatica Nakai (Aa-EE) was used as reported previously [3]. Piceatannol (Picea) and PP2 were obtained from Calbiochem (La Jolla, CA, USA). The enzyme immune assay (EIA) kits that were used to determine $\mathrm{PGE}_{2}$ levels were purchased from Amersham (Little Chalfont, Buckinghamshire, UK). Fetal bovine serum (FBS), penicillin, streptomycin, TRIzol Reagent, and RPMI1640 were purchased from GIBCO (Grand Island, NY, USA). RAW264.7 and HEK293 cells were acquired from ATCC (Rockville, MD, USA). The rest of chemical reagents used in this study were obtained from Sigma-Aldrich Co. (St. Louis, MO, USA). Phosphospecific or total-protein antibodies raised against p65, p50, c-Fos, c-Jun, inhibitor of $\kappa \mathrm{B} \alpha(\mathrm{I} \kappa \mathrm{B} \alpha)$, Src, spleen tyrosine kinase (Syk), p85, ERK, JNK, p38, lamin A/C, and $\beta$-actin were obtained from Cell Signaling Technology (Beverly, MA, USA).

2.2. Expression Vectors. Wild type Src (Src-WT), deletion mutants [Src kinase dead (Src-KD), Src-dSH2, and Src-dSH3] thereof, and point mutants [Src-constitutive active form (SrcCA) and Src-D404A] thereof were used as reported previously $[15,16]$. Luciferase constructs containing binding sites for NF- $\kappa$ B or AP-1 and adaptor molecules (MyD88 and TRIF) for TLR signaling were used as reported previously [17]. All constructs were confirmed by automated DNA sequencing.

2.3. Cell Culture and Drug Preparation. RAW264.7 cells, a murine macrophage cell line, and HEK293 cells were maintained in RPMI1640 media supplemented with $100 \mathrm{U} / \mathrm{mL}$ of penicillin, $100 \mu \mathrm{g} / \mathrm{mL}$ of streptomycin, and $10 \% \mathrm{FBS}$. The cells were grown at $37^{\circ} \mathrm{C}$ and $5 \% \mathrm{CO}_{2}$ in humidified air. The stock solutions of luteolin for the in vitro experiments were prepared in DMSO.

2.4. Determination of $N O$ and $P G E_{2}$ Production. Preincubated RAW264.7 cells or peritoneal macrophages $(1 \times$ $10^{6}$ cells $\left./ \mathrm{mL}\right)$ were treated with Aa-EE (0 to $\left.100 \mu \mathrm{g} / \mathrm{mL}\right)$, its constituents [luteolin (0 to $20 \mu \mathrm{M}$ ), eupatilin, jaceosidin], or standard compounds [PP2, piceatannol (Picea), L-NAME, or indomethacin] for $30 \mathrm{~min}$. After then, LPS $(1 \mu \mathrm{g} / \mathrm{mL})$ was further treated to the drug-treated cells for $24 \mathrm{~h}$. NO and
TABLE 1: Real-time PCR primers used in this study.

\begin{tabular}{lll}
\hline Name & & Sequence $\left(5^{\prime}\right.$ to $\left.3^{\prime}\right)$ \\
\hline \multirow{2}{*}{ iNOS } & F & GGAGCCTTTAGACCTCAACAGA \\
& R & TGAACGAGGAGGGTGGTG \\
\hline \multirow{2}{*}{ TNF- $\alpha$} & F & TGCCTATGTCTCAGCCTCTTC \\
& R & GAGGCCATTTGGGAACTTCT \\
\hline \multirow{2}{*}{ COX-2 } & F & GGGAGTCTGGAACATTGTGAA \\
& R & GCACATTGTAAGTAGGTGGACTGT \\
\hline \multirow{2}{*}{ GAPDH } & F & CAATGAATACGGCTACAGCAAC \\
& R & AGGGAGATGCTCAGTGTTGG \\
\hline
\end{tabular}

$\mathrm{PGE}_{2}$ production levels from 24-h culture supernatants were measured by Griess reagents and an EIA kit, as previously described [18].

2.5. Cell Viability Test. Before adding testing drugs to the cell suspension, RAW264.7 cells $\left(1 \times 10^{6}\right.$ cells $\left./ \mathrm{mL}\right)$ were recuperated for $18 \mathrm{~h}$, and the RAW264.7 cells were incubated with luteolin $(0$ to $20 \mu \mathrm{M})$ for an additional $24 \mathrm{~h}$. The cytotoxic effects of luteolin were then estimated using a MTT assay, as previously reported $[19,20]$.

2.6. mRNA Analysis Using Polymerase Chain Reaction. In order to determine cytokine mRNA expression levels, total RNA was isolated from LPS-treated RAW264.7 cells using TRIzol Reagent, according to the manufacturer's instructions. Total RNA was stored at $-70^{\circ} \mathrm{C}$ until use. Semiquantitative RT reactions were carried out as previously reported [21]. Quantification of mRNA was performed by real-time RTPCR with SYBR Premix Ex Taq according to the manufacturer's instructions (Takara, Shiga, Japan) using a real-time thermal cycler (Bio-Rad, Hercules, CA, USA), as reported previously [22]. Semiquantitative RT-PCR was conducted as previously reported with minor modifications [23]. All of the primers (Bioneer, Daejeon, Korea) used are listed in Table 1.

2.7. Preparation of Cell Lysates and Nuclear Fractions for Immunoblotting Analysis. To lyse RAW264.7 or HEK293 cells $\left(5 \times 10^{6}\right.$ cells $\left./ \mathrm{mL}\right)$, these cells were added with lysis buffer prepared with cold PBS containing $1 \mathrm{mM}$ sodium orthovanadate, $20 \mathrm{mM}$ Tris- $\mathrm{HCl}, \mathrm{pH} 7.4,2 \mathrm{mM}$ EDTA, $2 \mathrm{mM}$ ethyleneglycotetraacetic acid, $50 \mathrm{mM} \beta$-glycerophosphate, $1 \mathrm{mM}$ sodium orthovanadate, $1 \mathrm{mM}$ dithiothreitol, $1 \%$ Triton X-100, $10 \%$ glycerol, $10 \mu \mathrm{g} / \mathrm{mL}$ aprotinin, $10 \mu \mathrm{g} / \mathrm{mL}$ pepstatin, $1 \mathrm{mM}$ benzimide, and $2 \mathrm{mM}$ PMSF for $30 \mathrm{~min}$, with rotation, at $4^{\circ} \mathrm{C}$. To remove cell debris, the lysates were centrifuged at $16,000 \times \mathrm{g}$ for $10 \mathrm{~min}$ at $4^{\circ} \mathrm{C}$ and supernatants of the whole lysates were then stored at $-20^{\circ} \mathrm{C}$ until needed. Nuclear lysates were prepared by a three-step method, as previously reported [24]. After treatment, the cells were harvested with a rubber policeman, washed with $1 \times \mathrm{PBS}$, and lysed in $500 \mu \mathrm{L}$ of lysis buffer containing $50 \mathrm{mM} \mathrm{KCl}, 0.5 \%$ Nonidet P-40, $25 \mathrm{mM}$ HEPES (pH 7.8), $1 \mathrm{mM}$ phenylmethylsulfonyl fluoride, $10 \mu \mathrm{g} / \mathrm{mL}$ leupeptin, $20 \mu \mathrm{g} / \mathrm{mL}$ aprotinin, and $100 \mu \mathrm{M}$ 1,4-dithiothreitol (DTT) on ice for $4 \mathrm{~min}$. Cell lysates were then collected using 
a microcentrifuge at $14,000 \mathrm{rpm}$ for $1 \mathrm{~min}$. During the second step, the pellet (the nuclear fraction) was washed once with wash buffer without Nonidet P-40. During the final step, the nuclei were resuspended in an extraction buffer consisting of the lysis buffer plus $500 \mathrm{mM} \mathrm{KCl}$ and $10 \%$ glycerol. The nuclei/extraction buffer mixture was frozen at $-80^{\circ} \mathrm{C}$ and then thawed on ice and centrifuged at 14,000 rpm for $5 \mathrm{~min}$. The supernatant was collected as the nuclear extract.

Whole cell or nuclear lysates were then separated by immunoblotting analysis. Proteins were loaded on 10\% SDSpolyacrylamide gels and transferred by electroblotting to polyvinylidenedifluoride (PVDF) membranes. Membranes were blocked for $60 \mathrm{~min}$ in Tris-buffered saline containing $3 \%$ FBS, $20 \mathrm{mM} \mathrm{NaF}, 2 \mathrm{mM}$ EDTA, and $0.2 \%$ Tween 20 at room temperature. The membranes were incubated for 60 min with specific primary antibodies at $4^{\circ} \mathrm{C}$, washed 3 times with the same buffer, and incubated for an additional 60 min with HRP-conjugated secondary antibodies. The total and phosphorylated levels of p65, p50, c-Fos, c-Jun, $\mathrm{I} \kappa \mathrm{B} \alpha$, Src, Syk, p85, ERK, JNK, p38, HA, lamin A/C, and $\beta$-actin were visualized using an ECL system (Amersham, Little Chalfont, Buckinghamshire, UK), as reported previously [25].

\subsection{DNA Transfection and Luciferase Reporter Gene Activity} Assay. Overexpression experiments were performed with HEK293 cells $\left(1 \times 10^{6}\right.$ cells $\left./ \mathrm{mL}\right)$ by transfection with SykWT or mutants thereof $(1 \mu \mathrm{g} / \mathrm{mL}$ each $)$ using the PEI method in 12-well plates, as reported previously [26]. The cells were utilized for the experiments $24 \mathrm{~h}$ following transfection. Luteolin was added to cells $12 \mathrm{~h}$ before termination. For reporter gene assays, HEK293 cells $\left(1 \times 10^{6}\right.$ cells $\left./ \mathrm{mL}\right)$ were transfected with $1 \mu \mathrm{g}$ of plasmids expressing NF- $\kappa \mathrm{B}$-Luc or AP-1-Luc, as well as $\beta$-galactosidase, using the PEI method in 12 -well plates, according to the procedure outlined in a previous report $[26,27]$. Luciferase Assay System (Promega, Madison, WI, USA) was used to measure luciferase activity, as previously reported [28].

2.9. In Vitro Kinase Assay with Purified Enzymes and Immunoprecipitated Enzymes. In order to determine the inhibition of the kinase activities of Src or Syk using purified enzymes, the kinase profiler service from Millipore (Billerica, MA, USA) was employed. Purified Src or Syk (human) (1-5 mU) was incubated with the reaction buffer in a final reaction volume of $25 \mu \mathrm{L}$. After initiation of the reaction by adding Mg-ATP, the mixture was incubated for $40 \mathrm{~min}$ at room temperature, and then it was stopped by treatment of $5 \mathrm{~mL}$ of a 3\% phosphoric acid solution. The reaction mixture $(10 \mu \mathrm{L})$ was then spotted onto a P30 Filtermat, and then Filtermat was washed 3 times for $5 \mathrm{~min}$ in $75 \mathrm{mM}$ phosphoric acid and once in methanol prior to drying and scintillation counting.

In order to measure the usage of ATP by the Src kinase, Src was immunoprecipitated from lysates of WTSrc-overexpressing HEK293 cells with an anti-Src antibody. p85 was immunoprecipitated from untreated RAW264.7 cells using an anti-p85 antibody to serve as a kinase substrate. The kinase assay was carried out for $30 \mathrm{~min}$ at $30^{\circ} \mathrm{C}$ in a $50 \mu \mathrm{L}$ reaction volume including different concentrations of ATP, as well as other components, from a commercially available kinase assay kit (Upstate Biotechnology, Lake Placid, NY), as per the manufacturer's protocol and a previous report [29]. The incubation mixture was then further analyzed by immunoblotting to determine the kinase activity of immunoprecipitated Src with anti-phospho-p85.

2.10. Molecular Modeling Analysis. To understand the mode of binding of luteolin in the ATP-binding pockets of Src and Syk, a molecular modeling analysis of those ATP-binding pockets was performed using Sybyl version 8.02 (Tripos Associates) on the Red Hat Linux 4.0 operating system on an IBM computer (Intel Pentium 4, 2.8 GHz CPU, 1 GB memory), and the X-ray crystallographic structure of the activated Src ternary complex with the Src peptide was determined. The structure of luteolin was constructed in the Sybyl package using standard bond lengths and angles and was minimized using the conjugate gradient method. The Gasteiger-Huckel charge, with a distance-dependent dielectric function, was applied for minimization. The 1061 (PDB code) structure was chosen from the Protein Data Bank, and the structure was polished using the structure preparation tool in Sybyl. Luteolin was merged at Lys-295, Met-341, and Asp-404 as it exhibits $\mathrm{H}-\mathrm{H}$ bonding, and the obtained model complex was minimized using the subset minimization tool to produce a conformationally stable complex structure [30].

2.11. Statistical Analyses. All of the data presented in this paper are expressed as means \pm SD. For statistical comparisons, results were analyzed using either ANOVA/Scheffe's post hoc test or the Kruskal-Wallis/Mann-Whitney test. A p value $<0.05$ was considered to be a statistically significant difference. All statistical tests were carried out using the computer program, SPSS (SPSS Inc., Chicago, IL, USA). Similar data were also obtained using an additional independent set of in vitro experiments that were conducted using the same numbers of samples.

\section{Results}

3.1. Effect of Luteolin from Artemisia asiatica on Inflammatory Responses. To determine whether luteolin is able to suppress macrophage-mediated inflammatory responses, we tested the inhibitory profile of this compound using LPSand pam3CSK-treated RAW264.7 cells. As we expected, luteolin dose-dependently blocked the production of NO in RAW264.7 cells stimulated by LPS or pam3CSK (Figure 1(b)). In addition, this compound very strongly diminished the release of $\mathrm{PGE}_{2}$ under the same conditions (Figure $1(\mathrm{c})$ ). A cell viability test demonstrated that there was no cytotoxic activity of luteolin at its effective anti-inflammatory concentrations (Figure 1(d)). Because three major flavonoids (luteolin, jaceosidin, and eupatilin) have been identified in Artemisia asiatica [3, 31, 32], we next examined which flavonoid has the most potent activity. As Figure 1(e) shows, luteolin suppressed NO production to the greatest degree. We also confirmed the validity of our experimental conditions with additional experiments. Firstly, Aa-EE was able to dosedependently inhibit $\mathrm{NO}$ and $\mathrm{PGE}_{2}$ production (Figure $1(\mathrm{f})$ ), 
<smiles>O=c1cc(-c2ccc(O)c(O)c2)oc2cc(O)cc(O)c12</smiles><smiles>COc1ccc(-c2cc(=O)c3c(O)c(OC)c(O)cc3o2)cc1OC</smiles><smiles>COc1cc(-c2cc(=O)c3c(O)c(OC)c(O)cc3o2)ccc1O</smiles>

(a)

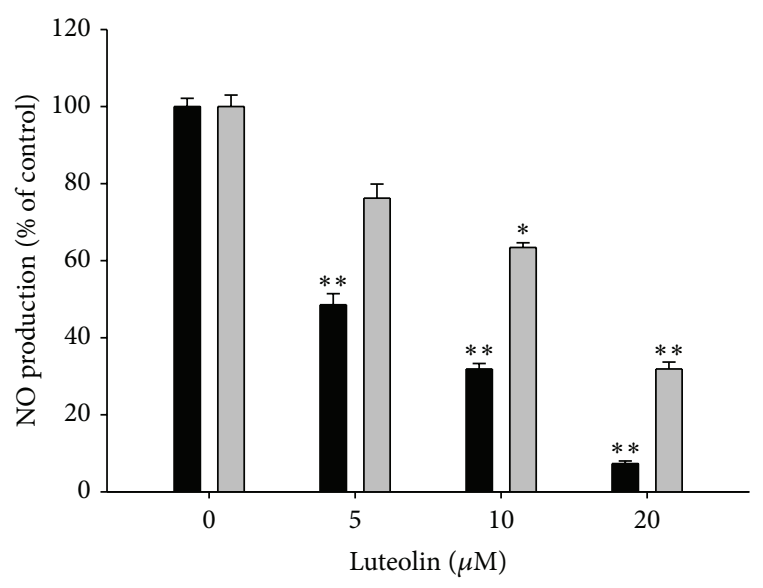

- LPS

$\square$ pam3CSK

(b)

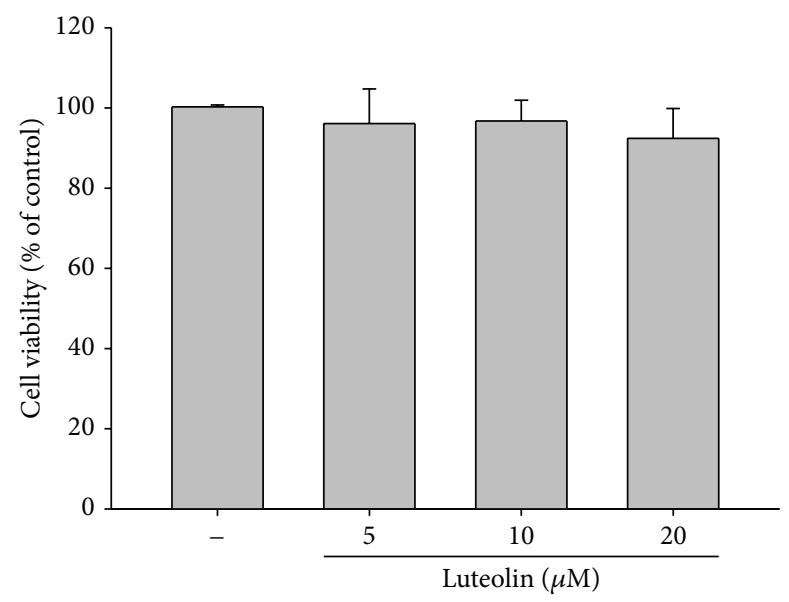

(d)

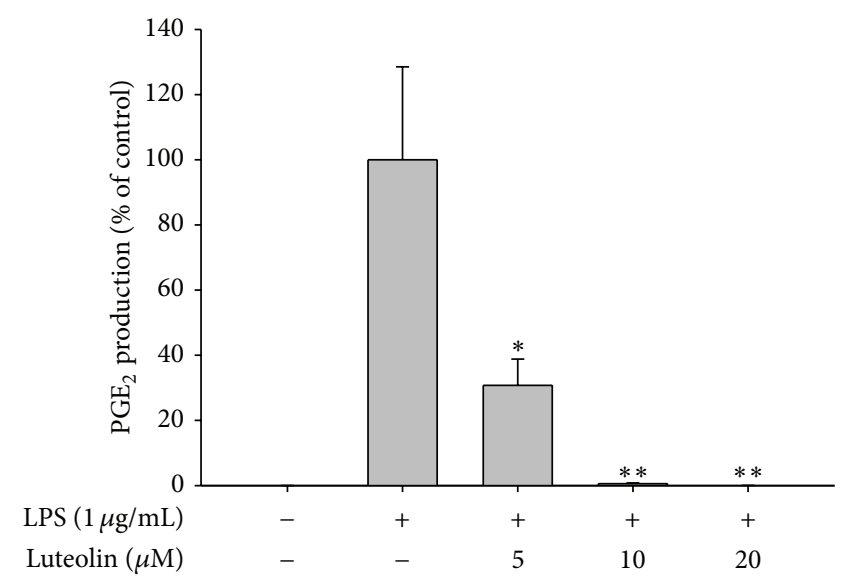

(c)

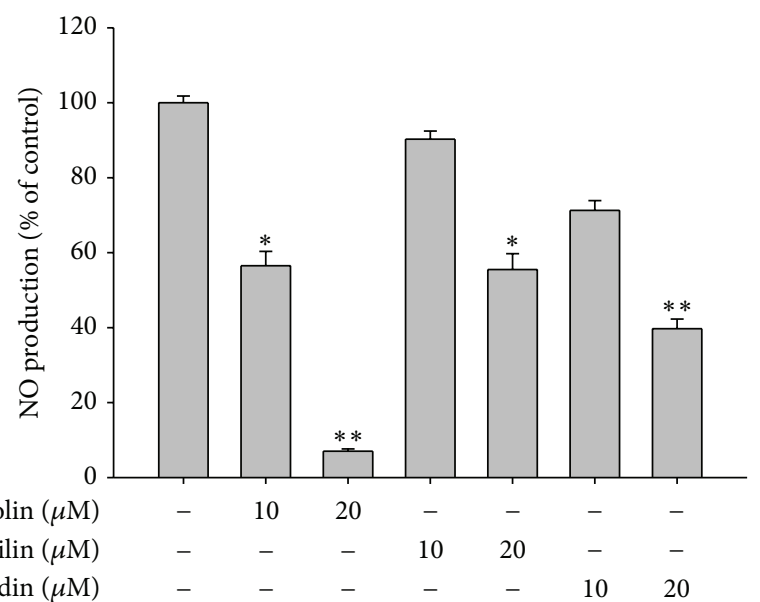

(e)

FIGURE 1: Continued. 


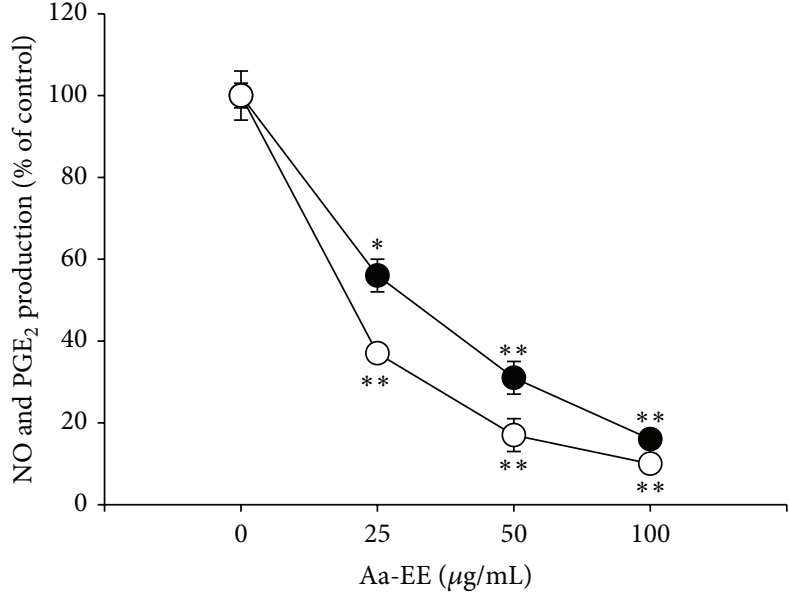

$-\mathrm{NO}$
$-\mathrm{PGE}_{2}$

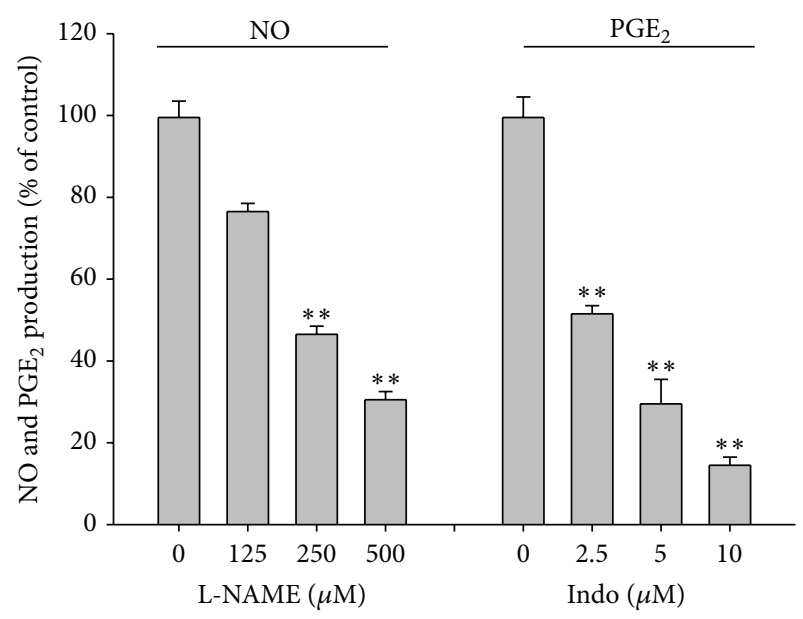

(g)

FIGURE 1: The effects of luteolin on the production of $\mathrm{NO}$ and $\mathrm{PGE}_{2}$ in macrophages, and their viability. (a) Chemical structures of luteolin, eupatilin, and jaceosidin. ((b), (c), (e), (f), and (g)) RAW264.7 cells $\left(1 \times 10^{6}\right.$ cells/mL) were treated with LPS $(1 \mu \mathrm{g} / \mathrm{mL})$ in the presence or absence of luteolin, eupatilin, jaceosidin, Aa-EE, or standard compounds [indomethacin (Indo) and L-NAME] for $24 \mathrm{~h}$. The supernatants were then collected, and the $\mathrm{NO}$ or $\mathrm{PGE}_{2}$ concentrations in the supernatants were determined using the Griess assay or EIA. (d) RAW264.7 cells $\left(1 \times 10^{6}\right.$ cells $\left./ \mathrm{mL}\right)$ were treated with luteolin for $24 \mathrm{~h}$. Cell viability was evaluated using the MTT assay. All data are expressed as the mean \pm SD of experiments, which were performed with six samples. ${ }^{*} p<0.05$ and ${ }^{* *} p<0.01$ compared to normal or control groups.

as reported previously [3]. Secondly, the standard compounds L-NAME and indomethacin (Indo) exhibited similar NO and $\mathrm{PGE}_{2}$ inhibitory profiles (Figure $1(\mathrm{~g})$ ), as reported previously [33].

\subsection{Effect of Luteolin on Transcriptional Activation in LPS-} Treated RAW264.7 Cells. To check whether the inhibitory activity of luteolin acts at the transcriptional level, we next investigated the mRNA levels of inflammation-mediating genes. As Figures 2(a) and 2(b) depict, luteolin suppressed the mRNA levels of TNF- $\alpha$, iNOS, and COX- 2 in a dosedependent manner. Similarly, the increased nuclear levels of p $50 / \mathrm{NF}-\kappa \mathrm{B}$ but not of $\mathrm{c}-\mathrm{Fos} / \mathrm{AP}-1$ or $\mathrm{p} 65 / \mathrm{NF}-\kappa \mathrm{B}$ by LPS were also suppressed by luteolin (Figure 2(c)). Finally, we obtained results indicating a similar inhibitory pattern via a reporter gene assay. Specifically, luteolin dose-dependently inhibited NF- $\kappa$ B-mediated luciferase activity stimulated by MyD88, an adaptor molecule linked to TLR4 (Figure 2(d)).

\subsection{Effect of Luteolin on Signaling Upstream of NF- $\kappa B$ Acti-} vation. Since we and other groups have demonstrated that inhibition of the NF- $\kappa$ B pathway could be the chief route by which luteolin mediates its effects, the luteolin-targeted molecules in this pathway were identified through the use of immunoblotting and kinase assays. As we expected, luteolin clearly diminished phospho-I $\kappa \mathrm{B} \alpha$ level at 15,30 , and $60 \mathrm{~min}$ after luteolin administration (Figure 3(a)). Unexpectedly, however, there was no inhibition of phosphorylation of ERK, p38, or JNK by luteolin, while it augmented the phosphorylation levels of these enzymes (Figure 3(b)), indicating that this compound is able to upregulate MAPK pathway rather than to inhibit. However, luteolin clearly suppressed the autophosphorylation of Src and Syk at 2 min, an optimal time to show the highest phosphorylation levels of Src and Syk, without altering the total levels thereof (Figure 3(c)). In agreement with this finding, luteolin completely suppressed the kinase activities of purified Src and Syk at a dosage of $20 \mu \mathrm{M}$ (Figure 3(d)), indicating that this compound might act as a direct inhibitor of these enzymes.

3.4. Mode of Inhibition of Src Kinase Activity by Luteolin. To further characterize the inhibitory mechanism of luteolinmediated suppression of Src activity, we next examined it using both wild type and mutant Src. As Figure 4(a) shows, luteolin strongly suppressed the phosphorylation of Src-WT and Src-CA, but not nonphosphorylated Src-KD. In addition, the phosphorylation levels of deletion mutants lacking the $\mathrm{SH} 2$ or SH3 domains were also reduced by luteolin, indicating that the target binding sites of luteolin to Src could not be the SH2 or SH3 domains (Figure 4(b)). Since several papers have suggested that some flavonoids are able to bind to ATP-binding pockets [34], we next investigated whether ATP can compete with luteolin at the ATP-binding pocket of Src. As we expected, an increase of ATP from 400 to $800 \mu \mathrm{M}$ abrogated the suppression of Src phosphorylation by luteolin (Figure 4(c)), indicating that luteolin can block the binding of ATP at Src's ATP-binding pocket. To assume which amino acids in ATP-binding site can associate with luteolin, a docking model was constructed using previously reported structural data [35]. Thus, it is speculated that the hydroxyl groups of luteolin seemed to form hydrogen bonds with residues Lys-295, Met-341, and Asp-404, which are important conserved sites in the ATP-binding domain 


\begin{tabular}{|c|c|c|c|c|}
\hline \multirow[b]{2}{*}{ LPS $(1 \mu \mathrm{g} / \mathrm{mL})$} & \multirow[b]{2}{*}{-} & \multicolumn{3}{|c|}{ RAW264.7 cells (6h) } \\
\hline & & + & + & + \\
\hline Luteolin $(\mu \mathrm{M})$ & - & - & 10 & 20 \\
\hline TNF- $\alpha$ & & $=$ & - & - \\
\hline iNOS & & - & 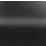 & \\
\hline COX-2 & & $=$ & - & 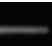 \\
\hline GAPDH & & 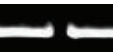 & & E \\
\hline
\end{tabular}

(a)

\begin{tabular}{|c|c|c|c|c|c|c|c|}
\hline \multirow[b]{2}{*}{ LPS $(1 \mu \mathrm{g} / \mathrm{mL})$} & \multirow[b]{2}{*}{-} & \multicolumn{2}{|c|}{$15 \mathrm{~min}$} & \multicolumn{2}{|c|}{$30 \mathrm{~min}$} & \multicolumn{2}{|c|}{$60 \mathrm{~min}$} \\
\hline & & + & + & + & $\overline{+}$ & + & $\overline{+}$ \\
\hline Luteolin $(20 \mu \mathrm{M})$ & - & - & + & - & + & - & + \\
\hline p65 & - & - & - & - & $\ldots$ & - & \\
\hline $\mathrm{p} 50$ & & 2 & 5 & $E$ & s & $=$ & $=$ \\
\hline c-Fos & & - & - & - & - & - & - \\
\hline Lamin $\mathrm{A} / \mathrm{C}$ & & & & & & & \\
\hline
\end{tabular}

(c)

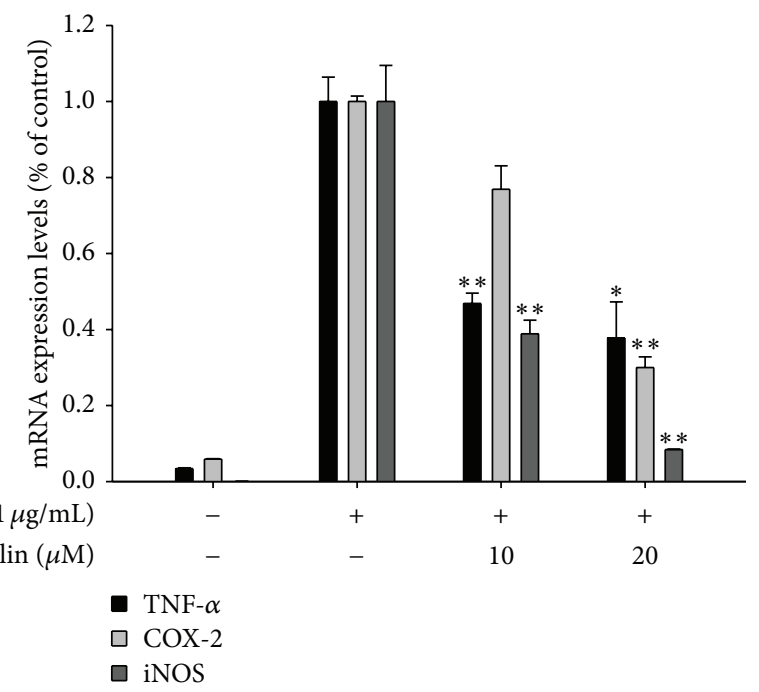

(b)

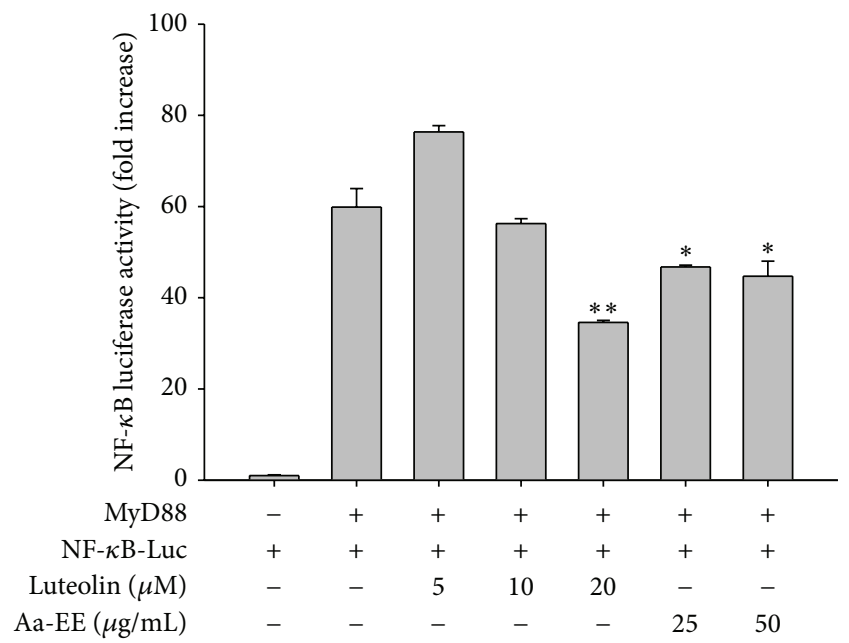

(d)

FIGURE 2: The effects of luteolin on iNOS, COX-2, and TNF- $\alpha$ gene expression and transcriptional regulation in LPS-treated RAW264.7 cells. ((a) and (b)) RAW264.7 cells $\left(5 \times 10^{6}\right.$ cells $\left./ \mathrm{mL}\right)$ were incubated with LPS $(1 \mu \mathrm{g} / \mathrm{mL})$ in the presence or absence of luteolin for $6 \mathrm{~h}$. iNOS, COX-2, and TNF- $\alpha$ mRNA levels were determined using RT-PCR (a) and real-time PCR (b). (c) RAW264.7 cells $\left(5 \times 10^{6}\right.$ cells $\left./ \mathrm{mL}\right)$ were incubated with LPS $(1 \mu \mathrm{g} / \mathrm{mL})$ in the presence or absence of luteolin for the indicated times. After preparing nuclear fractions, the levels of total translocated transcription factors (p65, p50, c-Fos, and c-Jun) were determined by immunoblotting analysis. (d) HEK293 cells cotransfected with NF$\kappa \mathrm{B}$-Luc $(1 \mu \mathrm{g} / \mathrm{mL})$ and $\beta$-gal (as a transfection control) plasmid constructs were treated with luteolin in the presence or absence of adaptor molecule (MyD88) for $12 \mathrm{~h}$. Luciferase activity was determined via luminometry. All data are expressed as the mean \pm SD of experiments. ${ }^{*} p<0.05$ and ${ }^{* *} p<0.01$ compared to the control group.

(Figure 4(d)). The importance of these sites was also confirmed by point mutations at these residues. In fact, these mutants (Src-D404A, Src-K294A, and Src-M341G) were not or less autophosphorylated, according to transfection work in HEP293 cells (Figure 4(e)). In addition, PP2 and piceatannol (Picea) (inhibitors of Src and Syk) inhibited the production of $\mathrm{NO}$ and $\mathrm{PGE}_{2}$ by LPS-treated RAW264.7 cells (Figure 4(f)).

\section{Discussion}

Although luteolin has been previously reported to exert anti-inflammatory activity via inhibition of both $\mathrm{NF}-\kappa \mathrm{B}$ and AP-1 $[10,36]$, in the present study, we focused on understanding the molecular mechanisms underlying NF$\kappa \mathrm{B}$ pathway inhibitory activity. Thus, this compound did not significantly suppress the AP-1 pathway, as evidenced by the finding that luteolin did not strongly suppress the phosphorylation of ERK, JNK, or p38 between 5 and 60 min after luteolin administration (Figure 3(b)). c-Fos, an AP-1 component, was also not decreased in the nuclear fraction of LPS-treated RAW264.7 cells but was enhanced instead (Figure 2(c)), in agreement with upregulation of ERK and p38 phosphorylation (Figure $3(\mathrm{~b})$ ). These results seem to raise a possibility that luteolin can negatively modulate dephosphorylation process of ERK and p38 by MAP kinase phosphatase-1. In addition, since other AP-1 subunits, such as 


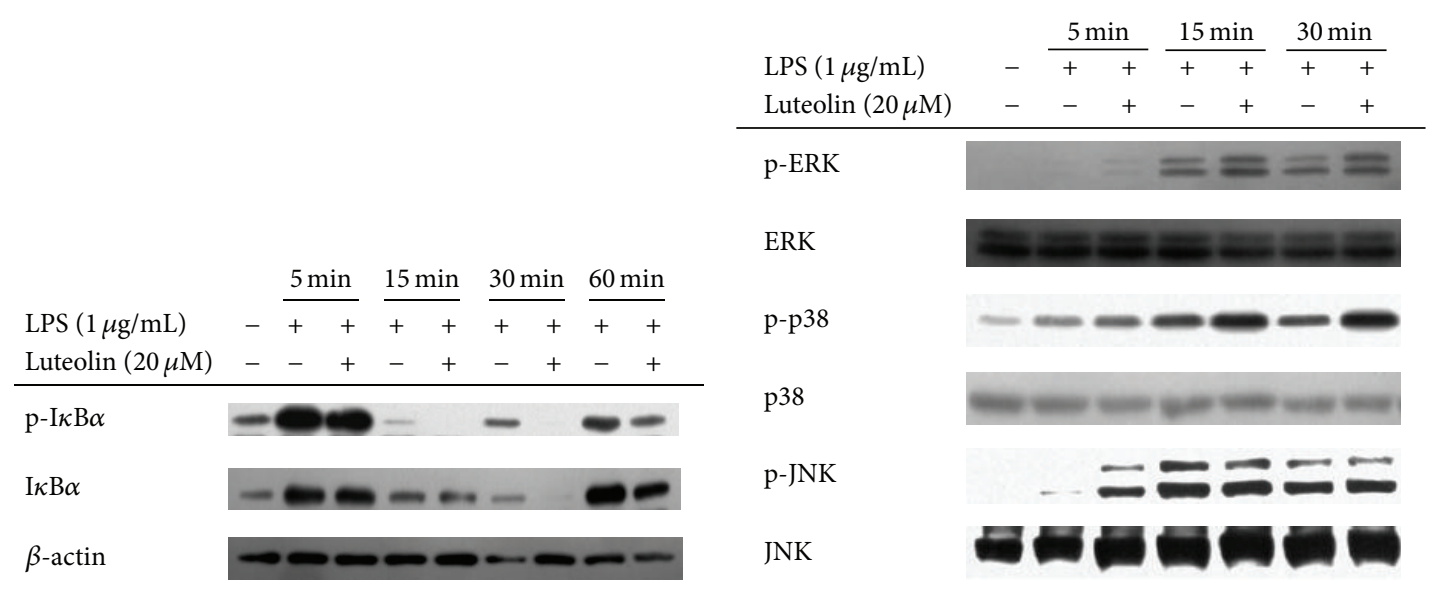

(a)

(b)

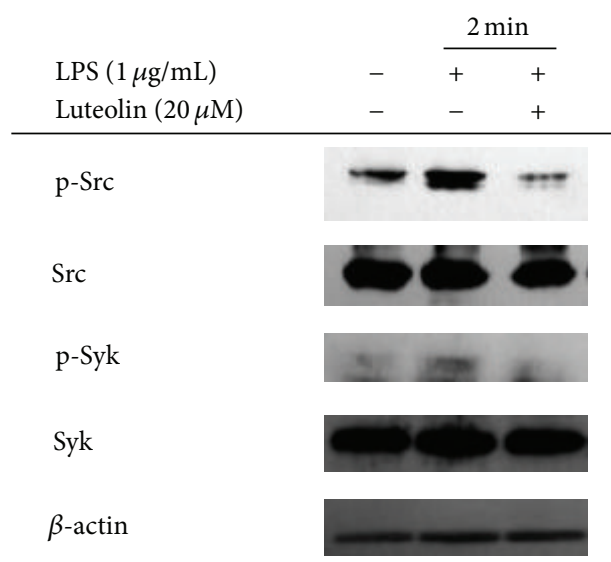

(c)

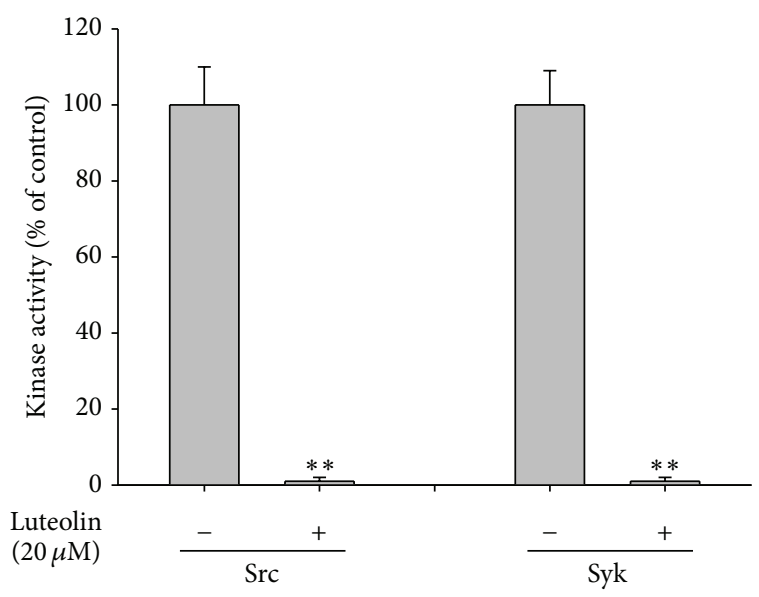

(d)

FiguRE 3: The effects of luteolin on the pathway upstream of NF- $\kappa$ B activation. ((a), (b), and (c)) RAW264.7 cells $\left(5 \times 10^{6}\right.$ cells $\left./ \mathrm{mL}\right)$ were incubated with LPS $(1 \mu \mathrm{g} / \mathrm{mL})$ in the presence or absence of luteolin for the indicated times. After preparing whole lysates, the levels of total or phosphorylated $\mathrm{I} \kappa \mathrm{B} \alpha$, Src, Syk, ERK, p38, and JNK were determined by immunoblotting. (d) The inhibitory effects of luteolin on Src and Syk activity were determined using a conventional kinase assay with purified Src and Syk. All data are expressed as the mean \pm SD of experiments. ${ }^{*} p<0.05$ and ${ }^{* *} p<0.01$ compared to the control group.

ATF-2, FRA-1, and c-Jun, have been reported to act positively in LPS-induced inflammatory responses, the possibility exists that luteolin is able to control those factors. Nonetheless, our results seem to strongly suggest that NF- $\kappa \mathrm{B}$ may be the major inhibitory pathway in the immunopharmacological actions of luteolin. Accordingly, nuclear levels of p65 at $15 \mathrm{~min}$, and of p50 at 30 and $60 \mathrm{~min}$, were reduced by luteolin (Figure 2(c)). NF- $\kappa$ B-mediated luciferase activity induced by MyD88 cotransfection was also significantly suppressed by $20 \mu \mathrm{M}$ of luteolin (Figure 2(d)). In addition, this compound clearly diminished the level of phospho-I $\kappa \mathrm{B} \alpha$ at 15,30 , and 60 min (Figure 3(a)).

Previously, we determined that Src and Syk are major $\mathrm{NF}-\kappa \mathrm{B}$ regulatory protein tyrosine kinases. It was found that the active forms of these proteins appear in response to LPS stimulation at early time points, between 1 and 5 min [21]. We and other groups have also demonstrated that specific inhibitors of these enzymes, namely, PP2 and piceatannol, suppress the production of $\mathrm{NO}$ and $\mathrm{PGE}_{2}$ (Figure $4(\mathrm{f})$ ) and the expression of proinflammatory cytokines [37]. It has been reported that phosphorylation of Syk and Src contributes to the induction of early (within $1 \mathrm{~h}$ ) phosphorylation of $\mathrm{I} \kappa \mathrm{B} \alpha$, linked to early nuclear translocation of $\mathrm{NF}-\kappa \mathrm{B}[21$, 38 ], suggesting that the initial activation of $\mathrm{NF}-\kappa \mathrm{B}$ might be controlled by these two kinases. In fact, suppression of Syk and Src by piceatannol and PP2 was found to inhibit early $\mathrm{I} \kappa \mathrm{B} \alpha$ phosphorylation and subsequent activation of NF- $\kappa \mathrm{B}$ [21]. The fact that luteolin suppressed nuclear translocation of p65 at $15 \mathrm{~min}$ and p50 at 30 and $60 \mathrm{~min}$ (Figure 2(c)) could be due to direct blockade of Syk and Src. Similarly, NF- $\kappa$ B-targeting anti-inflammatory methanolic or ethanolic extracts from known medicinal plants such as Evodia lepta, Rhodomyrtus tomentosa, Hopea odorata, and Cerbera manghas and synthetic or naturally occurring compounds such as quercetin and (5-hydroxy-4-oxo-4H-pyran2-yl)methyl 6-hydroxynaphthalene-2-carboxylate were identified as potent inhibitors of these enzymes [39, 40]. These results strongly indicate that Src and Syk could be important players in inflammatory responses and that targeting these enzymes with those modulators could contribute to their 


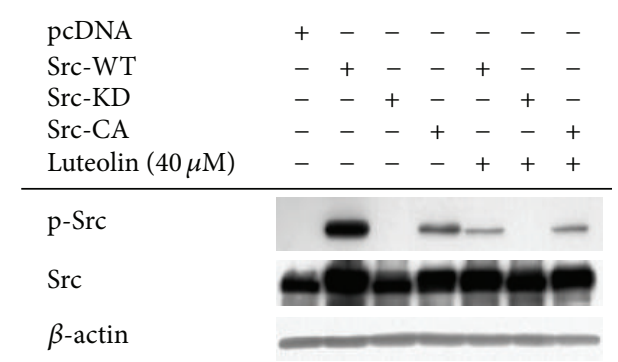

(a)

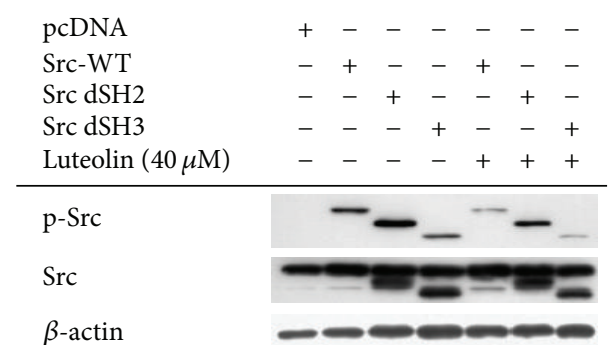

(b)

\begin{tabular}{llllll} 
ATP $(\mu \mathrm{M})$ & - & 400 & 400 & 800 & 800 \\
Src & + & + & + & + & + \\
p85 & + & + & + & + & + \\
Luteolin $(20 \mu \mathrm{M})$ & - & - & + & - & + \\
\hline Src & & & & &
\end{tabular}

(c)
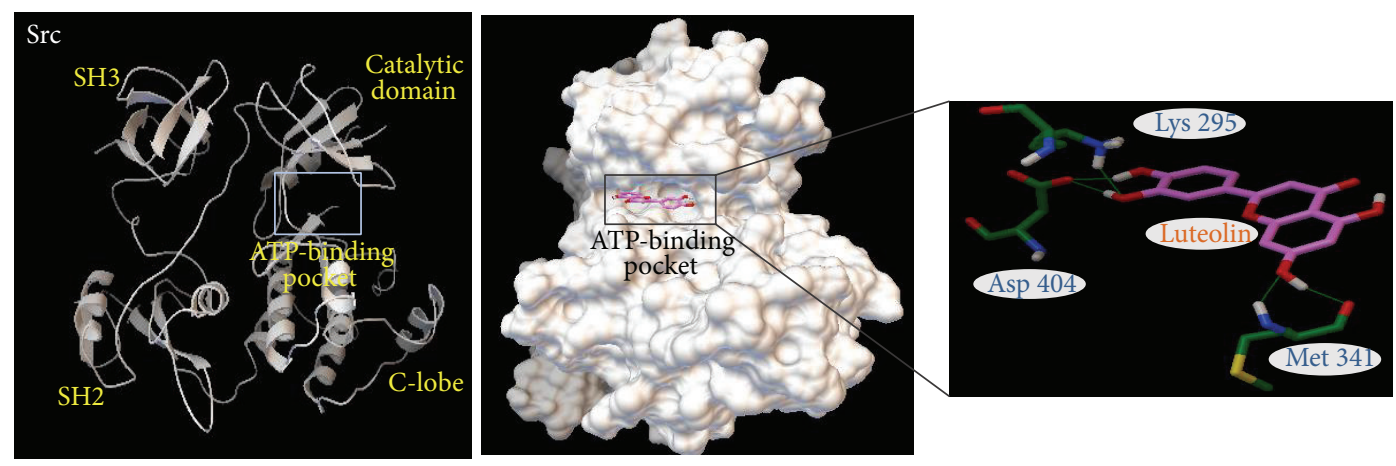

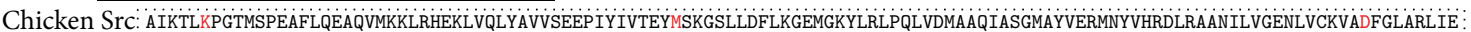
Mouse Src AIKTLKPGTMSPEAFLQEAQVMKKLRHEKLVQLYAVVSEEPIYIVTEYMNKGSLLDFLKGETGKYLRLPQLVDMSAQIASGMAYVERMNYVHRDLRAANILVGENLVCKVADFGLARLIE

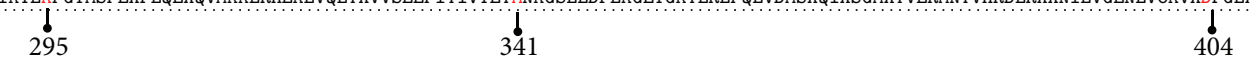

(d)

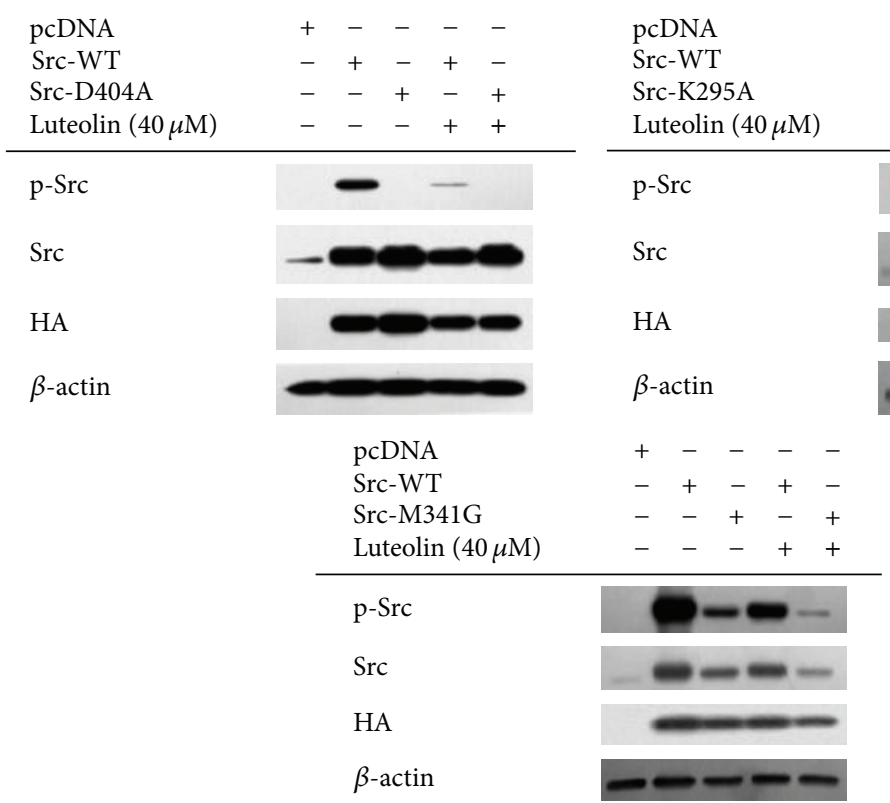

(e)

FIgURE 4: Continued. 


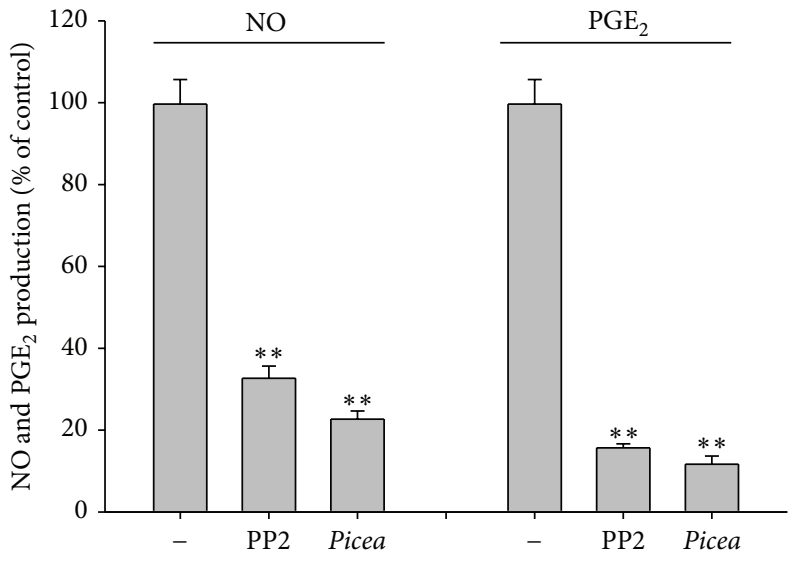

(f)

FIGURE 4: The mode of inhibition of Src kinase activity by luteolin. ((a), (b), and (e)) HEK293 cells $\left(5 \times 10^{6}\right.$ cells $\left./ \mathrm{mL}\right)$ were transfected with Src-WT, Src-KD, Src-CA, Src-dSH2, Src-dSH3, Src-D404A, Src-K295A, or Src-M341G in the presence or absence of luteolin. After preparing whole lysates, the levels of total or phosphorylated Src, HA, and $\beta$-actin were determined by immunoblotting. (c) Kinase assays were performed using immunoprecipitated Src as the enzyme, and immunoprecipitated p 85 as the substrate, in the presence of ATP and luteolin. Src activity was determined by measuring the levels of phospho-p85 by immunoblotting analysis. (d) The putative binding site of luteolin in the ATP-binding pocket of Src. (f) The inhibitory effects of PP2 or piceatannol (Picea) on the production of NO or PGE 2 were examined using the Griess assay and EIA. All data are expressed as the mean \pm SD of experiments that were performed with six or three samples. ${ }^{*} p<0.05$ and ${ }^{* *} p<0.01$ compared to the control group.

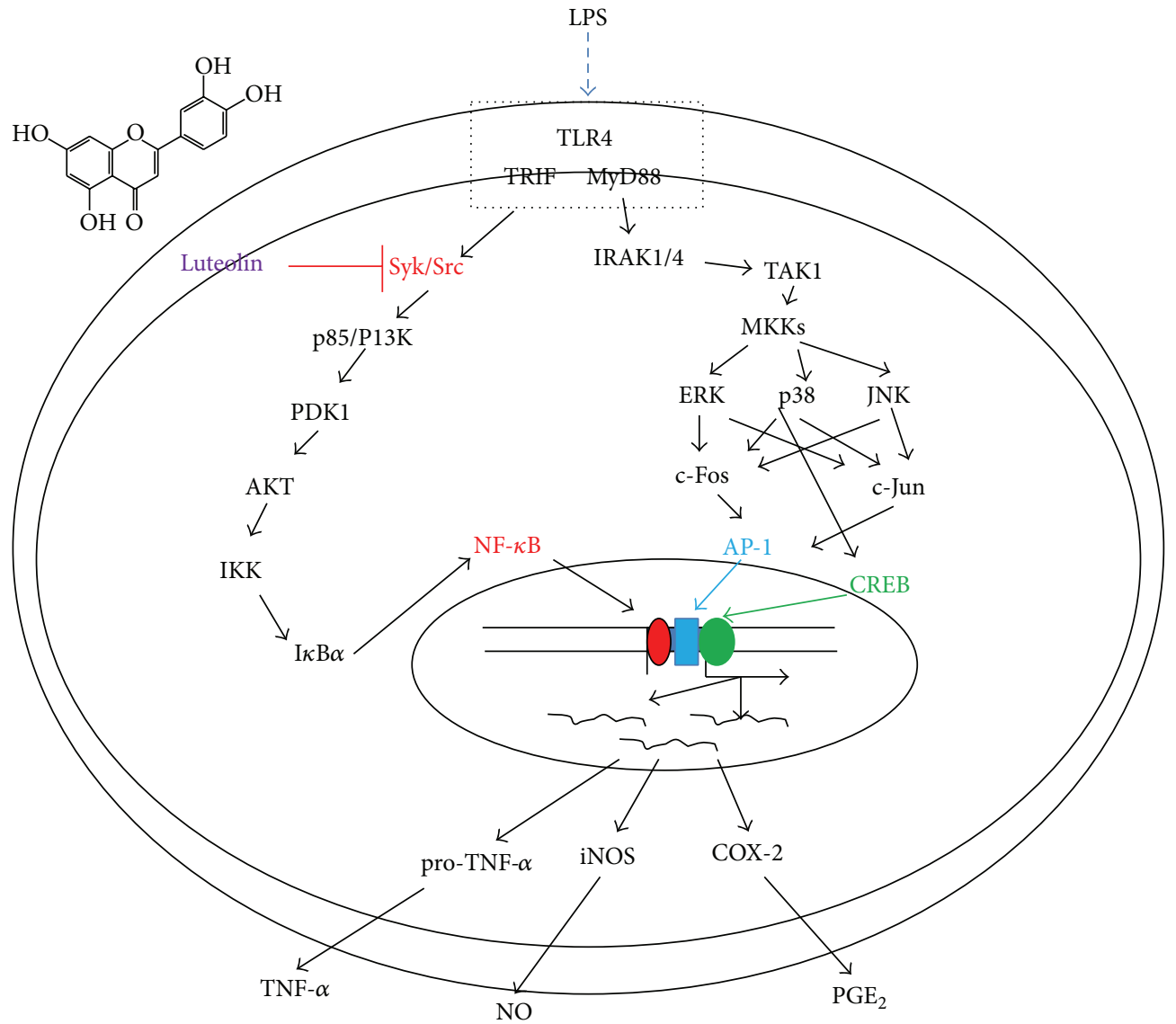

FIGURE 5: Putative mechanism of inhibition of macrophage-mediated inflammatory signaling events by luteolin. 
anti-inflammatory responses. We also verified that luteolin, with its strong anti-inflammatory activity, is able to directly block the kinase activity of both Src and Syk (Figure 3(d)), according to our kinase assay results. Our additional studies have also strongly supported the conclusion that there is direct binding of luteolin at the ATP-binding pockets of Src and Syk. For example, increased levels of ATP abrogated the suppressive activity of luteolin (Figure 4(c)). Furthermore, mutations at putative binding sites in the ATP-binding pocket, such as Asp-404, Lys-295, and Met-341, which are conserved between chicken and mouse, clearly diminished the phosphorylation of Src (Figures 4(d) and 4(e)), implying that these sites are critical for ATP binding and thus that luteolin may bind at these important amino acid residues, thereby mediating its suppression of these kinases. So far, however, it is not yet clear which function groups in luteolin are critical in the suppression of Src or Syk. Therefore, in future studies we will further examine this topic by exploring structure-activity relationships of structurally similar flavonoids.

In summary, we have shown that luteolin is capable of effectively suppressing in vitro inflammatory responses, in addition to possessing a radical-scavenging activity. In particular, we found that luteolin serves as a direct inhibitor of Src and Syk, thereby playing a central role in the activation of $\mathrm{NF}-\kappa \mathrm{B}$, as summarized in Figure 5. Since luteolin is present in many edible plants and fruits, we propose that luteolinrich fractions from edible sources could be utilized for the development of therapeutic foods with anti-inflammatory properties.

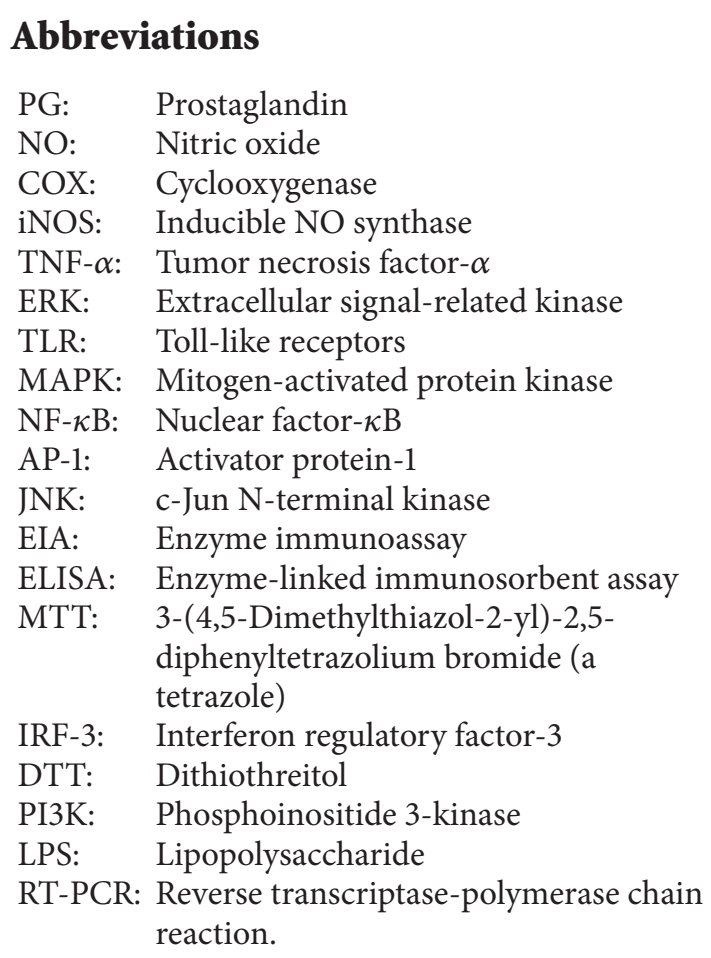

\section{Disclosure}

The authors alone are responsible for the content and writing of the paper.

\section{Conflict of Interests}

The authors have no conflict of interests to report.

\section{Acknowledgment}

This work was supported by Konkuk University (2014, to Jeong-Oog Lee).

\section{References}

[1] H. J. Song, C. Y. Shin, T. Y. Oh, and U. D. Sohn, “The protective effect of eupatilin on indomethacin-induced cell damage in cultured feline ileal smooth muscle cells: involvement of HO1 and ERK," Journal of Ethnopharmacology, vol. 118, no. 1, pp. 94-101, 2008.

[2] K. Huh, T. H. Kwon, U. S. Shin et al., "Inhibitory effects of DA9601 on ethanol-induced gastrohemorrhagic lesions and gastric xanthine oxidase activity in rats," Journal of Ethnopharmacology, vol. 88, no. 2-3, pp. 269-273, 2003.

[3] D. Jeong, Y.-S. Yi, G.-H. Sung et al., "Anti-inflammatory activities and mechanisms of Artemisia asiatica ethanol extract," Journal of Ethnopharmacology, vol. 152, no. 3, pp. 487-496, 2014.

[4] M. R. Alavala, J. Y. Lee, H. S. Jee et al., "Artemisolide from Artemisia asiatica: nuclear factor-kappaB (NF-kappaB) inhibitor suppressing prostaglandin E2 and nitric oxide production in macrophages," Archives of Pharmacal Research, vol. 29, no. 7, pp. 591-597, 2006.

[5] D.-H. Kim, H.-K. Na, T. Y. Oh, W.-B. Kim, and Y.-J. Surh, "Eupatilin, a pharmacologically active flavone derived from Artemisia plants, induces cell cycle arrest in ras-transformed human mammary epithelial cells," Biochemical Pharmacology, vol. 68, no. 6, pp. 1081-1087, 2004.

[6] D. Kalemba, D. Kusewicz, and K. Świąer, "Antimicrobial properties of the essential oil of Artemisia asiatica Nakai," Phytotherapy Research, vol. 16, no. 3, pp. 288-291, 2002.

[7] J. E. Son, E. Lee, S. G. Seo et al., "Eupatilin, a major flavonoid of artemisia, attenuates aortic smooth muscle cell proliferation and migration by inhibiting PI3K, MKK3/6, and MKK4 activities," Planta Medica, vol. 79, no. 12, pp. 1009-1016, 2013.

[8] M. Cai, P.-T. T. Phan, J. G. Hong et al., "The neuroprotective effect of eupatilin against ischemia/reperfusion-induced delayed neuronal damage in mice," European Journal of Pharmacology, vol. 689, no. 1-3, pp. 104-110, 2012.

[9] L. Zhu, W. Bi, D. Lu, C. Zhang, and X. Shu, "Luteolin inhibits SH-SY5Y cell apoptosis through suppression of the nuclear transcription factor- $\kappa \mathrm{B}$, mitogen-activated protein kinase and protein kinase B pathways in lipopolysaccharide-stimulated cocultured BV2 cells," Experimental and Therapeutic Medicine, vol. 7, no. 5, pp. 1065-1070, 2014.

[10] C. M. Park and Y. S. Song, "Luteolin and luteolin-7-O-glucoside inhibit lipopolysaccharide-induced inflammatory responses through modulation of NF-kappaB/Ap-1/PI3K-AKT signaling cascades in RAW 264.7 cells," Nutrition Research and Practice, vol. 7, no. 6, pp. 423-429, 2013.

[11] Y. Nishitani, K. Yamamoto, M. Yoshida et al., "Intestinal antiinflammatory activity of luteolin: role of the aglycone in NF$\kappa \mathrm{B}$ inactivation in macrophages co-cultured with intestinal epithelial cells," BioFactors, vol. 39, no. 5, pp. 522-533, 2013. 
[12] K.-C. Chen, C.-Y. Chen, C.-R. Lin et al., "Luteolin attenuates TGF- $\beta 1$-induced epithelial-mesenchymal transition of lung cancer cells by interfering in the PI3K/Akt-NF- $\kappa$ B-Snail pathway," Life Sciences, vol. 93, no. 24, pp. 924-933, 2013.

[13] S.-H. Park, J.-H. Kim, D.-H. Lee et al., "Luteolin 8-C- $\beta$ fucopyranoside inhibits invasion and suppresses TPA-induced MMP-9 and IL- 8 via ERK/AP-1 and ERK/NF- $\kappa$ B signaling in MCF-7 breast cancer cells," Biochimie, vol. 95, no. 11, pp. 20822090, 2013.

[14] C. Xie, J. Kang, Z. Li et al., "The açaí flavonoid velutin is a potent anti-inflammatory agent: blockade of LPS-mediated TNF- $\alpha$ and IL- 6 production through inhibiting NF- $\kappa \mathrm{B}$ activation and MAPK pathway," Journal of Nutritional Biochemistry, vol. 23, no. 9, pp. 1184-1191, 2012.

[15] K.-J. Yang, S. Shin, L. Piao et al., "Regulation of 3phosphoinositide-dependent protein kinase-1 (PDK1) by Src involves tyrosine phosphorylation of PDK1 and Src homology 2 domain binding," The Journal of Biological Chemistry, vol. 283, no. 3, pp. 1480-1491, 2008.

[16] S. E. Byeon, T. Yu, Y. Yang et al., "Hydroquinone regulates hemeoxygenase-1 expression via modulation of Src kinase activity through thiolation of cysteine residues," Free Radical Biology and Medicine, vol. 57, pp. 105-118, 2013.

[17] T. Shen, W. S. Yang, Y.-S. Yi et al., "AP-1/IRF-3 targeted anti-inflammatory activity of andrographolide isolated from Andrographis paniculata," Evidence-Based Complementary and Alternative Medicine, vol. 2013, Article ID 210736, 16 pages, 2013.

[18] C. K. Youn, S. J. Park, M. Y. Lee et al., "Silibinin inhibits LPSinduced macrophage activation by blocking p38 MAPK in RAW 264.7 cells," Biomolecules and Therapeutics, vol. 21, no. 4, pp. 258-263, 2013.

[19] R. Pauwels, J. Balzarini, M. Baba et al., "Rapid and automated tetrazolium-based colorimetric assay for the detection of antiHIV compounds," Journal of Virological Methods, vol. 20, no. 4, pp. 309-321, 1988.

[20] T. Yayeh, K.-H. Jung, H. Y. Jeong et al., "Korean red ginseng saponin fraction downregulates proinfl ammatory mediators in LPS stimulated RAW264.7 cells and protects mice against endotoxic shock," Journal of Ginseng Research, vol. 36, no. 3, pp. 263-269, 2012.

[21] Y. G. Lee, B. M. Chain, and J. Y. Cho, "Distinct role of spleen tyrosine kinase in the early phosphorylation of inhibitor of kappaB alpha via activation of the phosphoinositide-3-kinase and Akt pathways," International Journal of Biochemistry and Cell Biology, vol. 41, no. 4, pp. 811-821, 2009.

[22] G.-J. Kang, S.-C. Han, J.-W. Ock, H.-K. Kang, and E.-S. Yoo, "Anti-inflammatory effect of quercetagetin, an active component of immature Citrus unshiu, in HaCaT human keratinocytes," Biomolecules and Therapeutics, vol. 21, no. 2, pp. 138-145, 2013.

[23] S. H. Sohn, S. K. Kim, Y. O. Kim et al., "A comparison of antioxidant activity of Korean White and Red Ginsengs on $\mathrm{H}_{2} \mathrm{O}_{2}$-induced oxidative stress in HepG2 hepatoma cells," Journal of Ginseng Research, vol. 37, no. 4, pp. 442-450, 2013.

[24] S. E. Byeon, Y. G. Lee, B. H. Kim et al., "Surfactin blocks NO production in lipopolysaccharide-activated macrophages by inhibiting NF- $\kappa \mathrm{B}$ activation," Journal of Microbiology and Biotechnology, vol. 18, no. 12, pp. 1984-1989, 2008.

[25] J.-A. Lee, M.-Y. Lee, I.-S. Shin, C.-S. Seo, H. Ha, and H. K. Shin, "Anti-inflammatory effects of Amomum compactum on
RAW 264.7 cells via induction of heme oxygenase-1," Archives of Pharmacal Research, vol. 35, no. 4, pp. 739-746, 2012.

[26] T. Shen, J. Lee, M. H. Park et al., "Ginsenoside Rp1, a ginsenoside derivative, blocks promoter activation of iNOS and Cox-2 genes by suppression of an IKK $\beta$-mediated NF- $\kappa \mathrm{B}$ pathway in HEK293 cells," Journal of Ginseng Research, vol. 35, no. 2, pp. 200-208, 2011.

[27] S. B. Song, N. H. Tung, T. H. Quang, N. T. T. Ngan, K. E. Kim, and Y. H. Kim, "Inhibition of TNF- $\alpha$-mediated NF$\kappa \mathrm{B}$ transcriptional activity in HepG2 cells by dammaranetype saponins from Panax ginseng leaves," Journal of Ginseng Research, vol. 36, no. 2, pp. 146-152, 2012.

[28] K. K. Jung, H. S. Lee, J. Y. Cho et al., "Inhibitory effect of curcumin on nitric oxide production from lipopolysaccharideactivated primary microglia," Life Sciences, vol. 79, no. 21, pp. 2022-2031, 2006.

[29] T. Yu, J. Shim, Y. Yang et al., "3-(4-(tert-Octyl)phenoxy)propane-1,2-diol suppresses inflammatory responses via inhibition of multiple kinases," Biochemical Pharmacology, vol. 83, no. 11, pp. 1540-1551, 2012.

[30] J. Y. Lee, Y. G. Lee, K.-J. Yang et al., "Akt Cys-310-targeted inhibition by hydroxylated benzene derivatives is tightly linked to their immunosuppressive effects," The Journal of Biological Chemistry, vol. 285, no. 13, pp. 9932-9948, 2010.

[31] H.-J. Seo and Y.-J. Surh, "Eupatilin, a pharmacologically active flavone derived from Artemisia plants, induces apoptosis in human promyelocytic leukemia cells," Mutation Research: Genetic Toxicology and Environmental Mutagenesis, vol. 496, no. 1-2, pp. 191-198, 2001.

[32] Z. Hajdú, J. Hohmann, P. Forgo, I. Máthé, J. Molnár, and I. Zupkó, "Antiproliferative activity of Artemisia asiatica extract and its constituents on human tumor cell lines," Planta Medica, vol. 80, no. 18, pp. 1692-1697, 2014.

[33] M. J. Hossen, K. S. Baek, E. Kim et al., "In vivo and in vitro anti-inflammatory activities of Persicaria chinensis methanolic extract targeting Src/Syk/NF-kappaB," Journal of Ethnopharmacology, vol. 159, pp. 9-16, 2015.

[34] G. Lolli, G. Cozza, M. Mazzorana et al., "Inhibition of protein kinase CK2 by flavonoids and tyrphostins. A structural insight," Biochemistry, vol. 51, no. 31, pp. 6097-6107, 2012.

[35] R. Cao, N. Mi, and H. Zhang, "3D-QSAR study of c-Src kinase inhibitors based on docking," Journal of Molecular Modeling, vol. 16, no. 2, pp. 361-375, 2010.

[36] C.-Y. Chen, W.-H. Peng, K.-D. Tsai, and S.-L. Hsu, "Luteolin suppresses inflammation-associated gene expression by blocking NF- $\kappa \mathrm{B}$ and AP-1 activation pathway in mouse alveolar macrophages," Life Sciences, vol. 81, no. 23-24, pp. 1602-1614, 2007.

[37] M. J. Smolinska, N. J. Horwood, T. H. Page, T. Smallie, and B. M. J. Foxwell, "Chemical inhibition of Src family kinases affects major LPS-activated pathways in primary human macrophages," Molecular Immunology, vol. 45, no. 4, pp. 990 1000,2008

[38] Y. Yi, Y. Son, C. Ryou, G. Sung, J. Kim, and J. Y. Cho, "Functional roles of Syk in macrophage-mediated inflammatory responses," Mediators of Inflammation, vol. 2014, Article ID 270302, 12 pages, 2014.

[39] T. T. M. Dung, S. C. Kim, B. C. Yoo et al., "(5-Hydroxy-4-oxo4H-pyran-2-yl)methyl 6-hydroxynaphthalene-2-carboxylate, a kojic acid derivative, inhibits inflammatory mediator production via the suppression of Syk/Src and NF-kappaB activation," 
International Immunopharmacology, vol. 20, no. 1, pp. 37-45, 2014.

[40] M. Endale, S.-C. Park, S. Kim et al., "Quercetin disrupts tyrosine-phosphorylated phosphatidylinositol 3-kinase and myeloid differentiation factor-88 association, and inhibits MAPK/AP-1 and IKK/NF- $\kappa$ B-induced inflammatory mediators production in RAW 264.7 cells," Immunobiology, vol. 218, no. 12, pp. 1452-1467, 2013. 


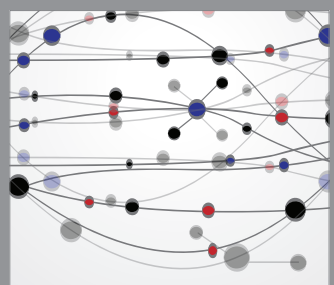

The Scientific World Journal
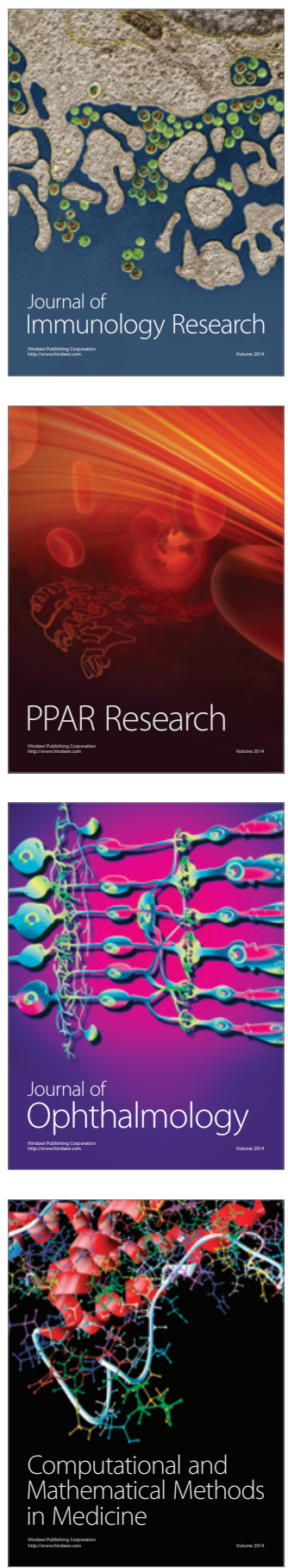

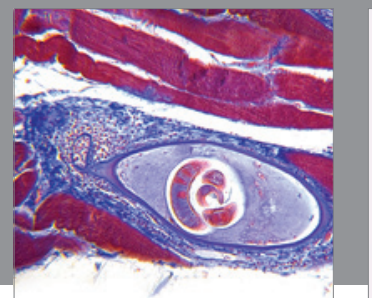

Gastroenterology

Research and Practice
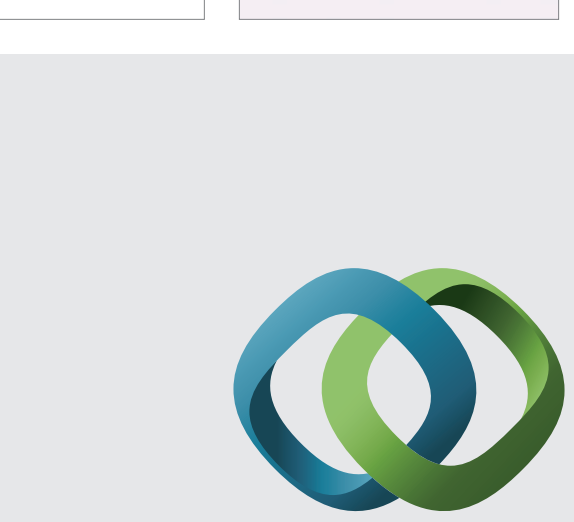

\section{Hindawi}

Submit your manuscripts at

http://www.hindawi.com
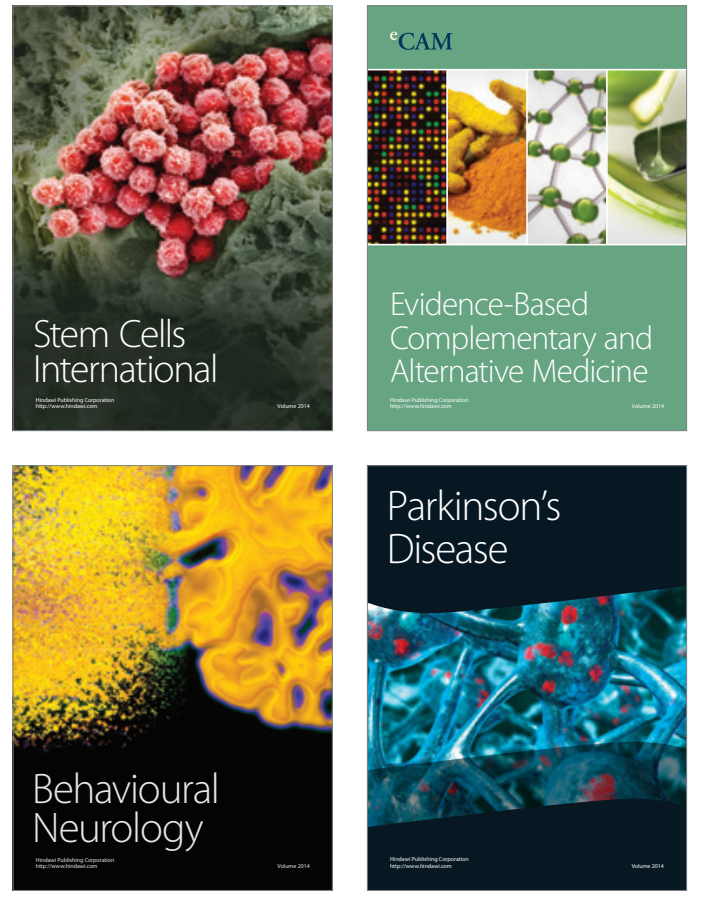
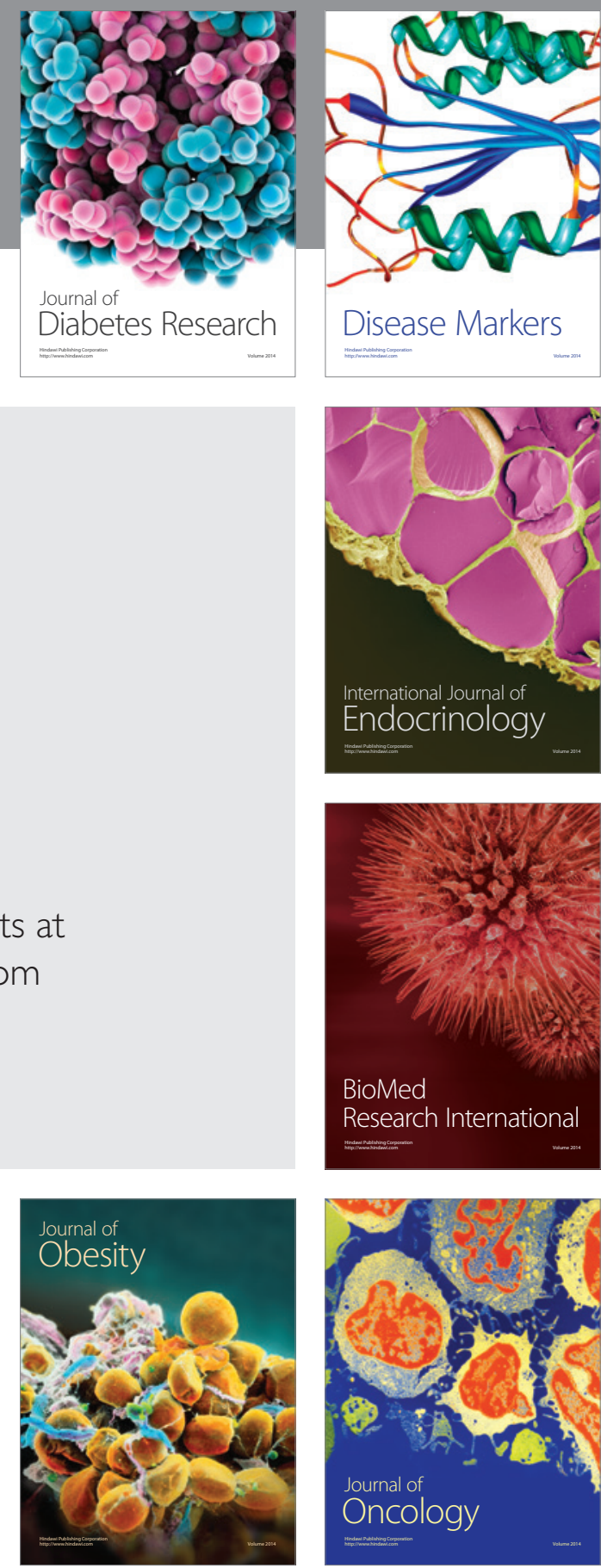

Disease Markers
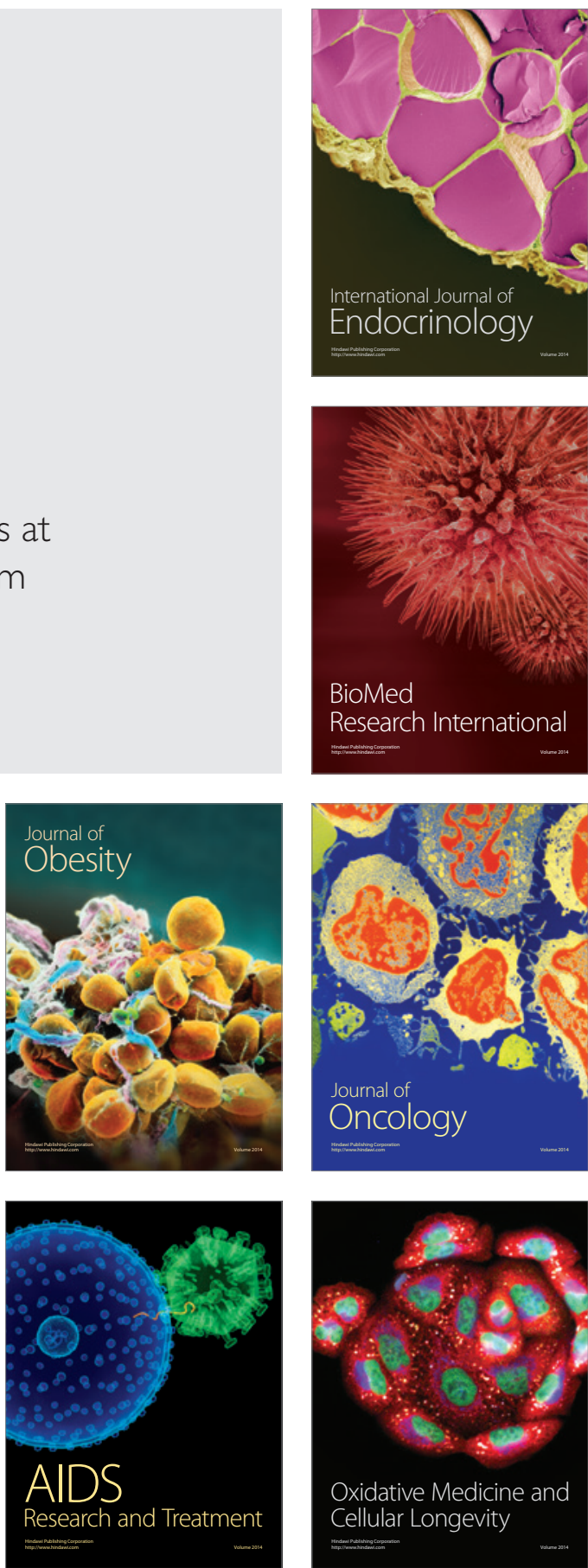